\title{
Political and Social Values amid Reformation of the Society and the Electoral Law in Russia
}

\author{
Arkadiy Shemelin $^{1} \&$ Evgeniy Drobotushenko ${ }^{1}$ \\ ${ }^{1}$ Transbaikal State University, Zabaykalsky Krai, Chita, Russia \\ Correspondence: Arkadiy Shemelin, Transbaikal State University, Zabaykalsky Krai, 672039, 30 \\ Aleksandro-Zavodskaya Street, Chita, Russia. Tel: 924-7-377-2828. E-mail: shemelin75@yandex.ru
}

Received: April 29, 2014 Accepted: May 23, 2014 Online Published: June 24, 2014

doi:10.5539/ass.v10n14p206 URL: http://dx.doi.org/10.5539/ass.v10n14p206

\begin{abstract}
The article asserts that moral priorities and the categories of fairness and the good have historically been a characteristic trait of the Russian intellectual community. The constitutional provisions for the rule of the people in the Soviet era largely changed the worldview of the Russians, but the electoral practice, created a negative attitude towards the idea of the formation of government bodies and participation in this process. Complexities of renewal of the electoral law consisted in the fact that the Russian reformers tried to adapt the Western concepts of constitutional law to conditions of a post-communist state. The period of democratic transformation in Russia became the longest, most confrontational and vulnerable in comparison to other former socialist states. Effectively, while acknowledging international standards, no one in Russia was willing to obey those acting in the role of teaching missionaries. Formation of bodies of people power took place under low quality of electoral law norms, and what are most important-in complicated conditions of establishment of liberal values, which resulted in the fact that the process of their establishment caused rejection of the liberal values themselves and raised a crucial issue of implementation of moral principles, related to the electoral process
\end{abstract}

Keywords: electoral law, social values, election process, political consciousness, society, moral principles, intellectual community, Russian philosophy, justice, political life

\section{Introduction}

The article examines the impact of the value categories of the Russian voters on the electoral process. So far the problems of adherence to moral values in the electoral process have been studied insufficiently, and the author attempts to fill this gap in this article. The article asserts that moral priorities and the categories of fairness and the good have historically been a characteristic trait of the Russian intellectual community. The constitutional provisions for the rule of the people in the Soviet era largely changed the worldview of the Russians, but the electoral practice (predictable voting results, non-competitive elections system, etc.) created a negative attitude towards the idea of the formation of government bodies and participation in this process. The author comes to the conclusion that the assertion of liberal values (private property, separation of the branches of government, transition to the market economy) in the Russian reality without consideration of the electoral culture, in which prominent places had been held by the categories of "fairness", "equal rights", and "morality", had a negative impact on the electoral process. The Russian voters did not deny the value of the electoral right as a mechanism to establish the rule of the people, but its practical implementation (consideration of interests of specific groups, conflicts of constitutional law, aporia between the citizen's electoral right and the civil duty, relation between private (corporate) and public funding of electoral campaigns, etc.) made fairness an issue of primary importance.

\section{Discussion of the Topic}

In the first section "Discussion concerning the attitude of foreign researchers to problems of electoral law, political and social values, and democratic transformations in Russia", the author gives brief overview of opinions of foreign researchers concerning the problems of electoral law in terms of democratic transit and expresses his view on the given problems. In section two, "Political Rationalism and the Role of the State in the Formation of the Essence of Public Mind", the author discusses the issues of interaction between the democratic transition and the political and social values of the Russian society. The article shows the views of the Russian scholars on the problems of morality and legal consciousness, appraising the role of the state in the 
process of formation of public mind. In section three, "The Role of Legal Consciousness and Ethical Principles in the Electoral Process", the author proves the importance of studying ethical principles in the context of electoral law. A conclusion is made that the need for public expression of a unity of mind and collective participation for a long time allowed the Soviet electoral law to be restricted to the establishment of the elections procedure, almost without touching the issues of protection or rights. The fourth section, "Civil Society and Private Property in the Political Life of Russia", describes the category of civil society in the context of the electoral process, determining the impact of establishment of private property in Russia on the attitude to democracy. Section five, "Value System of the Citizens and Democratic Transitions in the Circumstances of Society Reformation", presents the differences between the Western and Russian value systems. The author makes a conclusion about the mutual relation between the democratic transition and the establishment of generally accepted rules and principles in the area of electoral law. Section six, "Problems of Formation of Mass Holders of Electoral Values in Russia", analyzes the difficulties of reforming the electoral right in the circumstances of democratic transformations. A conclusion is made that the formation of mass holders of electoral values is a prerogative of the state and its legal institutions.

\subsection{Discussion Concerning the Attitude of Foreign Researchers to Problems of Electoral Law, Political and Social Values, and Democratic Transformations in Russia}

There are two groups of authors of democracy definitions. The first one (Huntington \& Przeworski) focuses on electoral law as the only practical democratic criterion. The other group (Rawls \& Arblaster) believes it cannot be defined by elections alone. They state the democratic society is characterized not only by free and fair elections but also by broadly defined pluralism. They see democracy as liberal and democratic. Others also consider social and economic democracy, social equality guarantees, or at least some level of social justice. The democratization in Russia can be seen through two main approaches. The first one employs popular theories of "transition" and rejects cultural explanations. The other uses the traditional stereotype of Russian political culture which states Russia's cultural tradition of authority to reject liberal democracy. The second approach is clearly simplistic and stunted, since it is static by definition and does not allow any significant change of political culture. As Larry Diamond put it "Whether changing or enduring, political culture does shape and constrain the possibilities for democracy." Michael McFaul sees today's Russia as a country that has completed its transition to electoral democracy, where all major political actors have "acquiesced to a new, albeit minimal, set of rules of political competition in which popular elections were recognized as the only legitimate means to political power." To become a democracy, Russia should develop the fundamentals of liberalism and the rule of law. Instead of an emphasis on elections and discussions of abstract monetarist schemes, it is important to develop respect for law and order, create a working system of separated and mutually controlling powers, and guarantees real independence of the courts and the mass media. At the same time, the system of government should be strengthened, so that decisions of all branches and levels of government are respected both by individual citizens and various groups. This can be achieved by a strong reform-oriented authority that would encourage necessary changes in the political culture.

\subsection{Political Rationalism and the Role of the State in the Formation of the Essence of Public Mind}

Transit to democratic values has demonstrably raised an issue of the nature of morals and rectitude in Russia and the existing historical ideological and psychological tendencies of evaluation and perception of external experience. The "Liberty, equality and fraternity" formula along with liberal values should be considered in terms of their facultative nature, as they are motivated by "different" from them objective properties and processes and are actualized only in the system of certain interactions between the subjects and objects (Baryshkov, 2005). Changes in the views and moods of Russians depended on the state of economy, social relations, reflected in internal politics, but also a major part was played by the level of morals, traditional historical tenets, and the common culture, which had formed before the reformation period.

Rationalism in politics asserts itself most vigorously when aiming at perfect solutions, gives rise to the politics of uniformity planting, and ignorance of the circumstances leads to the situation when there is no longer any place for diversity. The critical approach to rationalism in the Russian philosophy of the second half of the 19th and the beginning of the 20th centuries resulted in the problem of understanding the values of pragmatism: "The very concept of law has become completely obscure in the modern minds. It was relegated to practical interest as there is no longer any place for ideal principles (Chicherin, 1894-1898). The priority of moral principles and the search for them have always been a characteristic feature of the Russian intellectual environment, troubled by the low level of self-consciousness of the population, unsteadiness of the traditional principles, "falling away" and "renegading" "from the positive principles of living" (Novgorodtsev, 1990). 
Complex appraisal of the Russian nation lies in the fact that "the Russian nation in profound manifestations of its spirit is the least bourgeois from all nations, the least determined, the least chained to the limited forms of living, the one which values the established forms of life least of all." (Berdyayev, 1990). At the same time the Russian nation is characterized by aspiration to social justice, kindness, involvement, combined with the anarchy, inertness, indifference to imperfect good of practical living (Lossky, 1991).

Evaluating the role of the state in formation of nature of public consciousness, the Russian thinkers believed that "the state must take care of the common good and the purpose of science is "to clarify that the state power in itself is not the purpose, but merely the means of strengthening of internal welfare and sound civic consciousness, the success of which is estimated by the development of moral requirements" (Chicherin, 1894-1898).

Considering involvement of population in the political life, V.O. Klyuchevsky said: "In the West the law represents a political deal of two powers-the crown and the legislative assembly, in our country it is a will of one supreme power, though usually it is suggested by the (State.- A. Sh.) Council, which is manifested in the very formula of the highly approved opinions of the State Council: "having given heed to opinion of the Council", "so be it." But the Western legislative order is based on the idea of equality of two branches of power, we here, as basis of this order, have an idea of means and conditions for the most correct and prudent development of new legislative norms" (Klyuchevsky, 1993). The very idea to share power with the nation was not only doubtful, it was almost rebellious.

\subsection{The Role of Legal Consciousness and Ethical Principles in the Electoral Process}

Research of legal consciousness and ethical norms is important and is directly related to understanding of the processes, which took place in the public consciousness of Russians already in the modern epoch. The received right to vote and the related attainment of the right of option didn't lead to their automatic adoption in the consciousness of citizens as top-priority political and legal values.

Declaration of the nation's power in Soviet constitutions changed the world view of Russians in many ways, but the foreseeable voting results in the Soviet period led to the negative attitude not only to the very idea of formation of regulatory bodies, but of one's participation in this process as well. A situation of mass political estrangement emerged: "The political as such, the political of purely strategic orientation dies away at first in the representation system and finally-in the context of modern neo-configurationist idea. The socially significant disappears-and the politically significant, which depends on it, fades away" (Baudrillard, 2000). The estrangement process was characteristic of the whole Soviet period, where the ideological component exerted the dominant influence on ability of the population to express its own opinion and formation of pluralism as a form of existence. At that, a certain form of social homogeneity was being established along with the stability of the political system, sustained by myths.

According to the 1936 Constitution, election to the Deputy Councils of workers of all levels were held based on the total, equal and direct electoral law with secret ballot (p. 134). Limitations applied only to mentally challenged people, whose condition was recognized according to the established procedure. Special reservations were made for the voting rights of women. The right of nomination of candidates was secured to social organizations and societies of the working people: communist partisan organizations, professional unions, cooperative societies, youth organizations, cultural societies (p. 141) (Constitution, 1987). Leading positions were secured to the Communist Party, the leaders of which directly led the country. Succession of the essential principles of organization of public and political structure remained in the future as well, which was confirmed in the 1977 Constitution. Only in the Constitution dated December 26, 1990 we see changes, related to the loss by the Communist Party of the Soviet Union of its leading and directing role.

The ideological keynote, suggested by the party on behalf of the nation, put all forms of expression of the public opinion under control. The election itself was rather of a ritual character, the slogans during election campaigns, approved at that time, and asserted implementation goals of partisan and national economy projects.

Pre-election promises of the deputies touched upon the solution of only insignificant issues of economic importance. The period of election saw establishment of a single-option system, according to which only one candidate was suggested for one deputy seat. A special role in the election process was given to meetings of citizens, where candidates, previously recommended by partisan authorities, were nominated. Characteristics of the people power stressed the union of the nation and the power: "the state power embodies a concentrated manifestation of the nation's sovereignty, its full-fledged ruling authority. The nation externalizes its power through state power and through social power. The state power is organizationally embodied in the state, the social power-in social organizations. These are not two powers, but, essentially, a single power, supreme and sovereign, manifested through different forms" (Kabyshev, 1974). With such a definition of the problem it 
becomes clear that the institution of people power fitted well into the system, where there were completely no differences between the state power and the political power of the nation. In practice, it led to a situation, where the ruling party turned into the entity, which directly represented the nation.

The necessity of mass expression of the unanimity of opinion and collective participation were instrumental in the fact that the Soviet electoral right for a long period of time confined itself to establishing only of the procedure of the very elections and practically avoided the issues of rights protection, and only generally dealt with the issues of responsibility of certain electoral subjects. The established point on the absence of political competition in the socialist society served as grounds for substantiation of absence of regulation of the procedures of protection of active, passive and other electoral rights" (Akruchin, 2007).

Freedom of choice was not manifested in expressions, different from the suggested vision of the desirable political organization of the society. The question could only be about the framework of intellectual discussions. Naturally, the above-said had no relation to the electoral procedure. In the Soviet times rejection from participation in elections was looked upon as a negative opposition of individual and marginal groups to collective actions. Personal sovereignty was suppressed in the name of the nation's sovereignty and solidarity of the Soviet citizens. Granted that the concept of electoral rights is usually attributed to the group of political freedoms and rights of the citizens.

\subsection{Civil Society and Private Property in the Political Life of Russia}

The necessity of protection of electoral rights emerges in the context of rise of pluralism and polarization of opinion, which was possible under the conditions of a social conflict, as the terms of elections in the USSR were grounded on the idea of a social world. This is why the emergence of political movements and parties in the end of the 1980s and in the beginning of the 1990s raised doubt on the part of experts: attempts to introduce a multi-party system express only the opinion of an evident minority (Gordon, 1989).

The process of removing the society from the press of the state and the partisan dictate and search in the social environment of the forces needed for the formation of a democratic country became an important aspect of the formation of the new political system.

Introduction of the concept of a "civil society" in the political life of Russia meant a change of social organization of the society and, as such, the introduction of values, earlier politically rejected (Duka, 1997). The new introduced categories led to many problems of theoretical and practical character. It should be noted that methodologically the civil society is still lacking a solid definition. According to A. Ag, duplicity of the civil society shows itself not only in the forms of its manifestations, but in the approach to the problem as well. As such, "the functional approach rather is indicative of the absence of the civil society, the structural one - of its presence, but not in the "official legal" form, but in the form of a secondary, shadow sphere" (Ag, 1991).

Definitions of the value of the civil society concept in Russia are rather contradictory: "Civil society is a dangerous Russophobic chimera" (Dugin, 2014). In a different case, an obvious confusion of the civil society institutions and the political system is observed: political parties are characterized from the position of their identification as part of the civil society (Brygina, 2007).

Characterizing the civil society, it should be noted that integration of the civil society in the political life is limited by its life sphere. The civil society creates a sphere of private, mostly property-based relations and interests of people as free manufacturers and sovereign consumers, as independent and legally autonomous subjects of relations. This being the case, the civil society has a significant degree of autonomy regarding the political power and public institutions. Important here is the fact that the civil society provides environment for the development of different aspects of entrepreneurial activity, consumption ethics and professional morals. At the heart of internal communication there is understanding of such value as freedom of an individual.

This doesn't go in opposition with the fact that members of the civil society are conscious political actors, who participate in the democratic process. At the same time one has to acknowledge that the fear of disintegrative process came to be more important to Russia than determining what the civil society should turn into.

Adoption of the term "civil society" required the definition of not only the content but the factors or the terms under which it is implemented.

One of such factors was an introduction of the private property, which notoriously contradicted the previous ideas of the Soviet period. None the less problematic was validation of the ideas of subjectivity and autonomy of an individual, freedom and dignity in consciousness of the society. In practice, as we have already said, this led to sharp polarization of the society, major part of which couldn't transit to the group of owners. The group of poor people grew increasingly fast. The situation was worsened on account of unfavorable political, social 
and economic situation.

The goals of modernization of the country came into contradiction with an existing set of social principles and relations, which contradicted theoretical ideas of "constructive destruction", emphasizing undesirability of extremely quick and avalanchine destruction of the social and economic system, as this doesn't lead to validation of the new, but, quite the opposite, the old blocks the way of the new (Shumpeter, 1995). Highlighting the key points of the civil society was, in all likelihood, of an advisory character.

The general situation was exacerbated by growth of the private sector, increase of the number of entrepreneurs, emergence of business elite. These new groups of Russian population had a significant difference from representatives of other sectors of public production and even more so from emerging extensive marginal groups in terms of their axiological orientation, psychology and behavior (The partisan..., 1994).

Validation of private property in Russia was reflected in estimations of the situation: The period of public protests democracy, aimed at demolition of existing regime, in 1992 was replaced by active criticism of "shock therapy", carried out by supporters of liberal transformations. Implementation of economic reforms in 1991-1992 was complicated by opposition of "branches of power" to one another under the conditions of declaration of the principle of division of powers, as an extremely important characteristic of a rule-of-law state, the ideal version of which was desired by the society and the state.

During the reforms participation of citizens in the electoral process reflected the crisis of cultural values, loss of natural traditions, devaluation of norms and loss of individual significance by the combined social and cultural subject (Pavlov, 1997). The really available right to vote, to individually determine the results of elections didn't lead automatically to validation of the political and legal values as prioritized ones in the people's consciousness, as values should be developed by all mature people. After all, to believe in democracy means for him to believe in human powers and such form of living, which doesn't merely tolerate personal initiative, but also stimulates it (Reale, 1997).

The ethical norms of the past continued preserving their relevance in Russia: in the voter's culture an important place was occupied by the categories of "justice", "equality of rights", "morals".

Political organization of any society is based on the certain level of consciousness of its citizens, providing for necessary legitimation of government and its institutions. The very fight for the social consciousness appears to be the leading motive of political life. It fits well into understanding of value as a form of expression of interests (Perry, 1950).

\subsection{Value System of the Citizens and Democratic Transitions in the Circumstances of Society Reformation}

Axiological guidelines of the Russian people have always been connected with ideas on justice. They clearly prevailed in the public consciousness over the ideas on freedom. "Analysis of spontaneous associations showed that the Russian ideas on justice correspond to three concepts:

1) moral kindness (truth, honesty);

2) equal value of all people;

3) just deserts.

And at that, the leading concept is that of "triumph of truth" or "kindness". Justice, therefore, served as a moral law in the society and in personal relationships and was a moral pivot of legal consciousness (using frequency of connections between the selected associations we determined that in the core of legal consciousness of the Russian respondents lay interrelated ideas on law, responsibility and justice)" (Zdravomyslova, 2004).

Axiological landmarks, firmly established among the Western citizens, differed from the Russian ones: in the Russian respondents' ideas on justice dominant is the moral approach, while in the French citizens' ideas-the legal one. Russian respondents also exhibited understanding of "justice as being associated with the legal sphere (mostly with court and activities of judges), however understanding of justice as a personal quality, moral principle of behavior and moral value significantly "superseded" the legal meaning of the concept" (Zdravomyslova, 2004).

The democratic transit and validation of commonly accepted norms and principles in the area of electoral law suggested development of a clear understanding of democracy by population. As "Different peoples or social and economic groups, organized in a democratic way, only abstractly have one and the same subject-the nation. Democracy may be militarist or pacifist, absolutist or liberal, centralist or decentralizing, and once again different in different epochs, not stopping to be the democracy" (Schmitt, 2000). 
As we remarked, democratic values were established with due account for the Russian reality, as the democratic principle is only valid in the aspect of its legitimacy, on the one hand, in terms of state legal relations, and on the other hand, as a principle of international law with its requirement to representation of the people (Schmitt, 2000).

Establishment of new social and political values led to the rise of conservative consciousness: previous social and ontological principles. The process of representation of the old political culture resulted from the fact that "social and ontological principles, unless they change significantly by themselves, not only limit the scale of acceptable innovations in the area of values and operational experience but also create pre-requisites for their subsequent return back to basics" (Biryukov, 2004).

Combination of the considered factors led to the protest vote of 1993 in the State Duma, when the population supported the Liberal Democratic Party of Russia and the Communist Party of Russia. Liberal institutions couldn't get the necessary support of the people. The pro-government block of Ye. Gaydar "The Choice of Russia" instead of 35-40\% of the votes by partisan lists got only $12 \%$.

The success of the Liberal Democratic Party of Russia at the elections was caused by the so-called "Zhirinovsky phenomenon", i.e. successful manipulation of the voters' political consciousness, ensured by technological methods. The leader of the Liberal Democratic Party of Russia in his policy statements used the moods of the Russian voters, with due account for their age and ideological sympathies. V. V. Zhirinovsky suggested preserving historical traditions, value of the state and patriotism. When proposing projects on the "development of Russia", he promoted the "Russian idea", consolidation of the Russian national identity, great power statehood, using the terminology of Solzhenitsyn. For paternalistically oriented part of population such ideas turn out to be congenial. The populism of slogans and speeches, extraordinary type of behavior of V. V. Zhirinovsky provided him with necessary publicity in the eyes of his own voters.

The same statements are made by G. A. Zyuganov, leader of the Communist Party of Russia. Using the terminology of Solzhenitsyn, he speaks about the "development" of Russia. Great power statehood, the Russian idea and national identity are key points of the expressed world perception, bringing together the thoughts of different epochs: "The ideas of the Russian great power statehood, spirituality, popular patriotism, mixed economy, Eurasian civilization, stable global development were reflected in the political and theoretical documents of the party" (Zyuganov, 1997). For paternalistically oriented part of the population such ideas turn out to be dear. The carnival type of behavior exhibited by V. V. Zhirinovsky provided the necessary publicity to this politician in the eyes of his own voters.

As we have remarked the special type of the politician's behavior, program statements of the parties, expectations of changes for the best, emergence of social groups and other factors were reflected in the political consciousness of voters owing to its communicative properties, determined the electoral preferences and formed the relevant models: client-based, program-based, reference group-based and others.

Introduction of stable ideas on new liberal and democratic values, as fundamental ones, in the people's consciousness required validation of their legal form, accompanied by fixation of political and social values, which were being established in Russia.

The Russian society didn't deny the value of law as a public regulator. However, the forming practice of legal regulation of electoral law at that time relied upon the interests of specific social groups-the newly distinguished the most well-to-do part, which brought the issue of social justice to the forefront.

Having successfully eluded the crisis, the national law of Russia absorbed the values of democratic character during revision of legislation. Since the electoral law became a basis, upon which different political forces relied, as "the legal norms may not turn into values during their gradual historical maturation within their own legal and axiological culture, but started being borrowed as self-valuable, desirable for achievement of the results of social transformations in the society" (Nenovsky, 1987).

The passed 1994 Federal Law "On Basic Guarantees of Electoral Rights of Citizens of the Russian Federation" and then the 1997 Federal Law "On Basic Guarantees of Electoral Rights and the Right of Citizens of the Russian Federation to Participate in a Referendum" due to existing political situation and absence of legislative experience in the elected deputies required improvement. Taking the chapter on electoral system out of the RF Constitution essentially led to the fact that initially the framework of electoral reform wasn't determined, and constitutional consolidation of electoral rights turned out to be minimized (Postnikov, 1997).

Absence of clear subject of regulation by the electoral law led to serious constitutional and legal collisions. For instance, draft law "On Public Control over Elections and Counting of Votes", passed by the State Duma two 
times in 1995 and 1996, wasn't approved by higher authorities. A certain aporia even emerged between the right of a citizen to elect and the civil duty, established during electoral campaigns. This clearly resonated with ideas on obligations.

The federal and regional electoral campaigns exposed many legislative problems, related to organization and holding of elections at all levels. Legal regulation gaps were identified in obligation to hold elections periodically, in a legal status of political parties as subjects of electoral process, in balance between the private (corporate) and state in financing electoral campaigns, in direct collisions between the norms of the Federal Law on essential guarantees of electoral rights and other acts of the federal and regional legislation, in incompleteness of legal regulation of different stages and electoral actions; in using of mass media.

Despite noted problems, the process of forming new electoral legislation, the electoral process gained momentum by developing the subject matter of norms of electoral legislation, its compliance with international legal standards. International observers noted that a step was made in the direction of making Russian citizens effectively equal (Makarycheva, 2014).

Having systemically incorporated international standards in its legal system, Russia acknowledged that observance and protection of rights of the person and the citizen, development and improvement of democratic institutions of civil will expression, procedures of their implementation in accordance with generally accepted principles and norms of international law based on the national constitution and legal acts is a purpose and an obligation of the Russian legal state.

None the less important was acknowledgment of the system of values, which are essentially important for determination of the country's democratic status. These obligations were not merely formally granted by the Russian Federation to the Russian citizens (specified international electoral standards: rights and freedoms for participation in free and periodically held elections), but also changed its internal legislation to implement them.

\section{Conclusion}

Complexities of renewal of the electoral law consisted in the fact that the Russian reformers tried to adapt the Western concepts of constitutional law to conditions of a post-communist state. The period of democratic transformation in Russia became the longest, most confrontational and vulnerable in comparison to other former socialist states. The process of cultural adaptation lingered on. Of interest is an opinion of the American political scientist Richard Rose, according to which 1993 saw Russia adopt "constitution without citizens", as the majority of Russians saw no connection with their day-to-day hassles and the system of power, established in Russia by the new Constitution (Makarycheva, 2014). Effectively, while acknowledging international standards, no one in Russia was willing to obey those acting in the role of teaching missionaries. Such an approach, as a rule, is enthusiastically supported by the crowd, as it complies with the interests of identity and validation of the national "ego". At that, the critical approach gives way to prejudices and myths. Along with that, in the present globalized world it is hard to isolate one from the ongoing processes, related to distribution of generally valid values.

The processes in the political life correspond to the processes, which are taking place on an above-individual level: "Although the process of social interactions is internally related both with personal characteristics of interacting individuals, and with cultural concepts, it, none the less, creates an individual, fourth system, which in the analytical sense is independent from the systems of individual, culture and organism. This independence becomes all the more evident when focus is on the requirements of integration, which is so much needed by the systems of social interactions because of their internal propensity to conflict and disorganization (I am referring to what is sometimes labeled as the problems of order in the society, classically formulated by Thomas Hobbes). The system of interactions is indeed a social system, which is a subsystem of the system of actions..." (Parsons, 1993). Extrapolation of the above-said on the process of political elections creates a more balanced situation. Connection is made between the political interests of groups with values of the whole society. In terms of validation of communicative connections and search of identity such a setting promotes the search of consolidation within the framework of a single commonality. According to T. Parsons, such consolidation is possible in terms of the theory of "social actions", where two factors interact-normative order and population organized in groups. "Development of an autonomous legal system is, possibly, the most important indicator of differentiation between the societal integrative system, focused on the societal community, and the political structure, related to selection, arrangement and attainment of collective goals in a bigger extent than maintaining solidarity (including the order) as such. Among all societies of the past the Roman society achieved the biggest progress in this direction" (Parsons, 1993).

Thus, formation of mass carriers of electoral values is a problem of the state and its legal institutions. Ideas on 
the nation's sovereignty are based on it being acknowledged as subject of the political system, which has a right for conscious and systemic participation in the political and legal relations. We believe that the concept of "nation", in terms of it being acknowledged as a subject of the political system, may not be looked at as a certain number of citizens, which comprise it, which is why the nation's sovereignty should not be considered a "total of the citizens' sovereignties" (Nesterenko, 2002). Here special terms of using the concept of "nation" as a subject of electoral legal relations should be stated explicitly. According to Yu. A. Vedeneyev and S. D. Knyazev: "The nation as a social and political phenomenon is a single source of power. But transfer of this power to elective bodies of state authority and local self-government bodies is affected through implementation of electoral rights, which don't belong to the nation but to the citizens of the Russian Federation. It's not fortuitous that it is they who act as main recipients of electoral legislations and are sole holders of constitutional right to elect and be elected to bodies of state authority and local self-government bodies.

Without the citizens and their participation legal electoral relations couldn't exist, as otherwise one would have to acknowledge that purpose of elections may be achieved without free expression of will of immediate holders of electoral rights" (Vedeneyev, 1998). The necessity to acknowledge legitimacy of government institutions and securing recognition of made decisions requires not only recognition of supreme, inalienable right of the nation to determine its destiny, be a single, independent from anybody and anything carrier and voicer of the supreme power in the state and the society, but also a collective participation and recognition at the level of individual people of a need for the "rule of the nation". The form of such participation is elections to representative institutions and during direct expression of will in the course of referenda. At that, there is a necessary rise of political subjectivity, and the elections themselves acquire the necessary value. It is important to note the interaction of individuals with external stimuli, the reaction to one's own needs and principles, the expectations, the actions of political institutions and generally accepted moral principles.

The principle of generality, which was fixed by the active and passive electoral law, completely corresponded to the liberal and legal approach (the triune formula: equal measure, freedom and justice) (Law et al., 1991).

In conclusion it should be said that formation of bodies of people power took place under low quality of electoral law norms, and what's most important-in complicated conditions of establishment of liberal values, which resulted in the fact that the process of their establishment caused rejection of the liberal values themselves and raised a crucial issue of implementation of moral principles, related to the electoral process.

\section{References}

Ag, A. (1991). Systemic analysis of the modern society. Political science yesterday and today, 1, 46-47.

Akruchin, A. R. (2007). Procedure of protection of electoral rights of citizens in the Russian Federation. abstract from the thesis of ... the candidate of legal sciences. Moscow: OMPT RAGS.

Baryshkov, V. P. (2005). The axiology of personal existence. Moscow: Logos.

Baudrillard, J. (2000). In the shadows of the silent majorities or the end of the social. Yekaterinburg: Publishing House of the Ural University.

Berdyayev, N. A. (1990). On Russia and the Russian philosophical culture. Philosophers of the Russian abroad after the October Revolution. Moscow: Nauka.

Biryukov, N. I., \& Sergeyev, V. M. (2004). Origin of institutions of representative authorities in modern Russia. Moscow: Agency "Publishing Service".

Brygina, V. I. (2007). Political and legal tendencies of growth of the role of political parties in the electoral process. Constitutional and municipal law, 19, 15.

Chicherin, B. N. (1894-1898). Course of state science: Part 3. Moscow.

Dugin, A. (2014). Project "Civil Society" as a threat to Russian identity. Retrieved from http://www.patriotica. $\mathrm{ru} /$ authors/dugin.html

Duka, A. V. (1997). The Civil society-looking for the way. St.P.

Gordon, L. A. (1989). Social science. Social politics. Economic reform. Moscow: Progress.

Kabyshev, V. T. (1974). Direct people power in the Soviet state. Saratov: Publishing House of Saratov University.

Kagan, M. S. (1997). Theory of Values philosophy. St.P.: TOO TK "Petropolis".

Klyuchevsky, V. O. (1993). The Russian history. Complete course of lectures in three books. Moscow: Mysl. 
Kukushkin, Y. S. (1987). Study of the History of Soviet Constitution. M.: Politizdat.

Law and Culture. (1991). Moscow: International relations.

Lossky, N. O. (1991). Terms of absolute goodness: Ethical principles; Character of the Russian nation. Moscow: Politizdat.

Makarycheva, M. G. (2014). Perception of the Russian transit in the USA Late confessions. Retrieved from http://www.irex.ru/press/pub/polemika/08

Nenovsky, N. (1987). Law and values. Moscow: Progress.

Nesterenko, A. V. (2002). Democracy: Problem of the subject. Social sciences and the present day, 4.

Novgorodtsev, P. (1990). Collection of articles on the Russian Revolution. Moscow: Publishing House of the Moscow University.

Parsons, T. (1993). The Concept of society: Components and their interaction. THESIS, 2, 98.

Pavlov, A.V. (1997). Elements of the philosophy of culture. Tyumen: TOGIRRO.

Perry, R. B. (1997). General Theory of Value. It's meaning and basic principles, construed in terms of interest. Cambridge: Mass.

Postnikov, A. Y. (1997). System of electoral legislation in the Russian Federation: Dissertation in the form of a scientific report in candidacy for the degree of doctor of legal sciences. $\mathrm{M}$.

Reale, J., \& Antiseri, D. (1997). Western philosophy from its origins to the present day. St. P.: TOO TK "Petropolis".

Schmitt, K. (2000). Political theology. Compilation. Moscow: KANON-press-Ts.

Shumpeter, J. (1995). Capitalism, socialism and democracy. Moscow: Ekonomika.

The partisan system in Russia in 1989-1993: History of Evolvement. (1994). Moscow: Nachala-Press.

Vedeneyev, Y. A., \& Knyazev, S. D. (1998). Legal electoral relations: Concept, political and legal content and structure. Herald of the Central Election Commission, 2(56), 75.

White Book of Russia (observations and suggestions in the area of human rights). (1994). Frankfurt am Main: International Society for Human Rights.

Zdravomyslova, O. M. (2004). Ideas on justice and equality, and legal experience of population (based on Russian-French research). World of Russia, 3, 73.

Zyuganov, G. A. (1997). October and the Present Day. Moscow: Inform-Znaniye.

\section{Copyrights}

Copyright for this article is retained by the author(s), with first publication rights granted to the journal.

This is an open-access article distributed under the terms and conditions of the Creative Commons Attribution license (http://creativecommons.org/licenses/by/3.0/). 